\title{
Evolution in action
}

\author{
Slowly, and with pressure from the scientific community, the structure and mission of a European Research \\ Council begins to develop
}

W e are all here because of the complete failure of the EU [European Union] to fund basic science in Europe." This provocative statement by Michael Ashburner from the University of Cambridge, UK, described the motivation for the 300 European scientists to gather at the UNESCO (United Nations Educational, Scientific and Cultural Organization) building in Paris, France, on 19 February 2003 to talk about the future of science and research in Europe. The European Life Sciences Forum, with support from UNESCO, the European Molecular Biology Organization and the Federation of Biochemical Societies, had organized a meeting to discuss the establishment of a European Research Council (ERC) to overcome the now accepted fact that Europe is lagging behind the USA in basic research. Although the discussions among the, predominantly European, life scientists showed that there are different visions of its identity and mission, one thing was definitely taken for granted-that the establishment of an ERC is needed and inevitable. François Gros, Perpetual Secretary of the French Academy of Sciences, echoed this sentiment in his talk: "[Setting up an ERC] is one of the most challenging proposals regarding the reorganization of science in Europe," adding a quote from the French novelist Victor Hugo: "Nothing is more powerful than an idea whose time has come." This sense of expectancy in the European scientific community has increased during the past few months, such that most parties from the scientists to the European Commission are now supporting the idea, albeit mainly verbally. As Phillippe Busquin, the European Commissioner for Research, made clear in his closing speech, it is now up to the scientists to work out the details and organize themselves to achieve the critical mass that

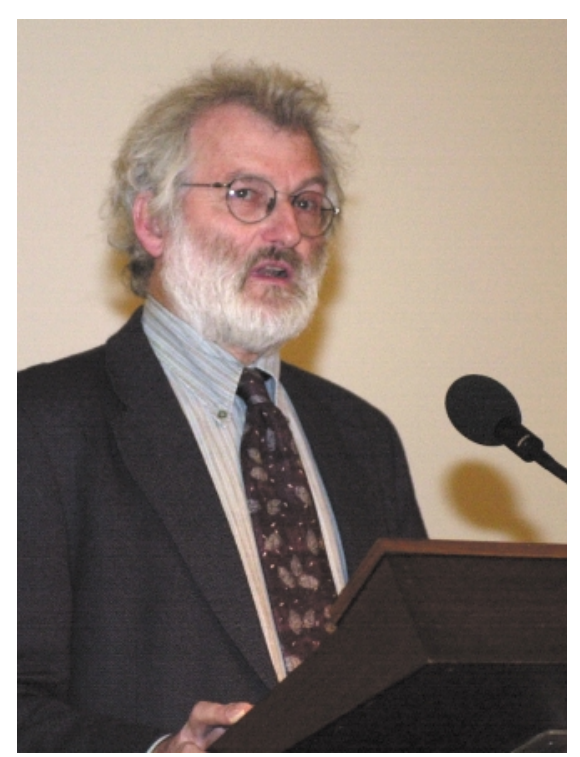

Fig. 1 I John Sulston, of the Sanger Centre, UK, and last year's winner of a Nobel Prize: "No single European nation is able to answer this big federal American challenge."

is needed to push the ERC through the numerous obstacles, pitfalls and traps on the political road to its creation. "If you want to do political lobbying, you need to do this with clear elements," he said. "But it is your job to move this forward."

Indeed, it is in scientists' best interests to heed this advice, mainly because they believe the ERC to be the magic cure for all the ailments that are now plaguing science and research in Europe. And these are numerous - the brain drain, fuzzy career structures, low salaries, lack of infrastructure and competition, and the focussing of politicians on expected returns. And at the same time, European biotech and pharmaceutical companies are moving their research enterprises to the USA, where they find a more fertile environment for their research. In short, the lack of scientific competition and the increasing gap between Europe and the USA are the main factors cited as to why Europe needs new structures, instruments and finances to catch up with the juggernaut that is American science. "We do have a gap to close and we'd better do it fast," Brian Clark from the University of Aarhus, Denmark, said. Indeed, out of the top 20 scientific institutions in the world, only three are European: the European Molecular Biology Laboratory in Heidelberg, Germany, at position 14, the Imperial Cancer Research Fund, now Cancer Research UK, in London, UK, at position 17, and the University of Cambridge, UK, at position 20 (Science Watch, January/February, 2; 2003).

A $\mathrm{s}$ manifold as the problems it is hoped the ERC will overcome are the ideas about the mission and scope of an ERC. The more modest ones envision the ERC as a fellowship scheme for postdoctoral researchers and young investigators. Several speakers, most notably German Nobel laureate Christine Nüsslein-Volhard, Director of the Max Planck Institute for Developmental Biology in Tübingen, Germany, called for a new grant scheme, likely to be modelled on the USA's Howard Hughes Investigators scheme or the German Leibniz Prize programme, to fulfil this role. The Howard Hughes scheme in particular was seen as "an example of how you can achieve quite a lot with relatively little money," as Mary Osborn, from the Max Planck Institute for Biophysical Chemistry in Göttingen, Germany, said. An ERC could thus start small "with whatever money we can get our hands on," she continued, and then gradually grow once it has shown that it adds value to the European scientific landscape.

But, for simple economic reasons, an ERC should be as large as possible, thinks John 
Sulston (Fig. 1) from the Sanger Centre, Cambridge, UK, and last year's winner of a Nobel Prize. Because if European governments do not invest in the expensive research infrastructure that scientists need, they will cede this to the USA, and eventually to US companies. "Europe needs the ability to tackle large projects and maintain them," Sulston said, so that it can become "a counterbalance to the influence of America, which too often tends to tip over in the interest of private companies." His vision of an ERC is as an agency, with a budget of several billion Euros, that mainly invests in infrastructure, its decisions based on scientific quality alone. And the budget needs to be large because "no single European nation is able to answer this big federal American challenge," Sulston said, so "Europe needs the concept of federal focus." And while we are at it, why not also use the money to establish and run independent European laboratories, modelled on CERN or EMBL, others asked.

Sulston's concept of an ERC is clearly not what most European presidents or prime ministers would like to see, as they all too often put their national, or even their own, interests above those of Europe. But even more radical is the vision presented by Nobel laureate Rolf Zinkernagel (Fig. 2), Head of the Institute of Experimental Immunology at University Hospital in Zürich, Switzerland,

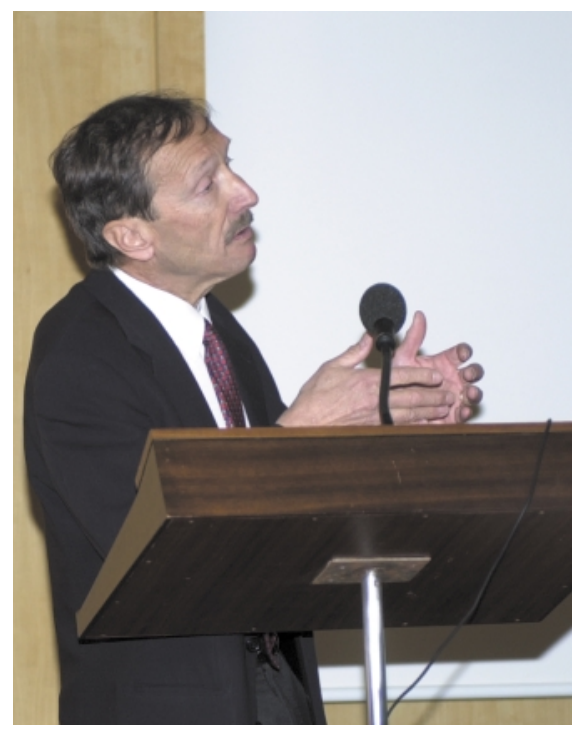

Fig. 2 | Nobel laureate Rolf Zinkernagel, Head of the Institute of Experimental Immunology at University Hospital in Zürich, Switzerland: “One of the most important goals of the ERC should be to spend European taxpayers' money wisely, with a long-term view." who obviously adopts the American adage 'Think big'. His idea of an ERC is nothing short of it being the main European funding agency for science, with a budget of $€ 20-40$ billion. "We need major financial means to have an impact on European science," Zinkernagel said, comparing his proposed budget with that of the US National Institutes of Health, which alone spends around US\$27 billion each year. And it should be run by scientists, based on scientific principles and independent of politicians' selfish wishes and interests. "One of the most important goals of the ERC should be to spend European taxpayers' money wisely, with a long-term view," Zinkernagel said.

$A$ Ithough personal ideas about an ERC are diverse, there was, nevertheless, unequivocal agreement on its principles: an ERC should be independent both of national and of European institutions; it should base its decisions on scientific principles alone, and be 'efficient and just'; it should have minimal bureaucracy and short, easy application procedures; it should fund the whole spectrum of science, including social sciences and the humanities; and it should be open to researchers from all over Europe, eventually defining Europe as reaching as far as Russia. And, despite some criticism from Slovakian attendants, an ERC should not adopt the principle of 'juste retour', meaning that member states get approximately the same amount back in research grants as they contribute, because its main goal should be to focus on the best institutions and scientists to increase the quality of science in Europe.

There are clear visions, but the reality is muddy, and the European scientific community must decide sooner rather than later what it actually wants. And the details of an ERC are still missing from the discussion, criticized Mogens Flensted-Jensen, Vice Chairman of the Board of the Danish Research Councils. Thus, before starting any negotiations with the European Commission (EC) or the national research councils, the scientific community first has to define the ERC's mission, instruments, ownership and accountability. This is "an example of how an ERC could be in the real world," said Flensted-Jensen. "I think we cannot sell idealism, and whatever proposal we bring forward must have practical aspects," Jean-Patrick Connerade, President of Euroscience, and Professor of Physics at Imperial College, London, UK, agreed. Kai

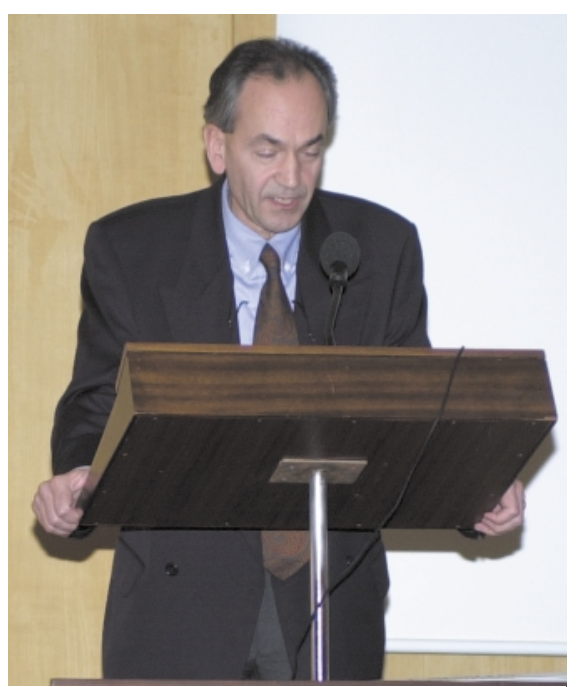

Fig. 3 | Peter Kind, Director of Directorate B of the European Commission's Directorate-General for Research: "An ERC should not compete with or duplicate existing structures" and "should create added value to Europe.”

Simons, Director of the Max Planck Institute of Molecular Cell Biology and Genetics in Dresden, Germany, and President of the European Life Sciences Organization, also thinks that the details of an ERC need to be worked out soon. This would put a structure in place by 2004 , when the EC starts discussing the budget for the 7th Framework Programme to be implemented in 2007. The $3 \%$ goal-the commitment by the European heads of state, made in Barcelona in 2001, to increase the EU's overall budget for R\&D from $1.9 \%$ to $3 \%$ of each country's gross domestic product-is another reason why an ERC should be established in the near future. As José Mariano Gago, a former Portuguese Minister of Science and Technology, pointed out, it will create a huge demand for additional scientists and technicians who need to be trained now.

A nd, of course, there remains the nagging question of where the money for an ERC should come from, at which point everybody raised their hands in defence and yelled "Not me!" It is questionable as to whether the national funding agencies will devote a considerable chunk of their

...the constitutional basis for any trans-national system is missing, and needs to be established in parallel with the ERC 
budgets to a pan-European agency without resistance. Nevertheless, the demands and complaints from the scientific community have already caused reactions among European officials. Ernst-Ludwig Winnacker, President of the Deutsche Forschungsgemeinschaft, Germany's largest funding agency, pointed out that many European agencies already contribute part of their budgets to trans-national research and/or allow scientists to spend their grant in another country. "In addition to the EU, there is a virtual ERC already in existence, which is, of course, deeply founded in the national research councils," Winnacker said. Nevertheless, the constitutional basis for any trans-national system is missing, and needs to be established in parallel with the ERC. "We eventually need a legal structure," Winnacker said. This, as he and others pointed out, would be the European Constitution that is now being discussed in the convention headed by Valéry Giscard $d^{\prime}$ Estaing, the former French President. In fact, the prospects for science and research at the proposal stage look good. The Constitution would replace the Treaty of Amsterdam, the current legal basis for the EU's business, which makes basic research the responsibility of national governments. Consequently, many participants felt a need to lobby the European Parliament and their national governments to ensure that science remains prominent during the Constitution's final formulation.

\section{... [scientists] believe the ERC to be the magic cure for all the ailments now plaguing science and research in Europe}

It is also questionable as to whether the EC would be willing to take a chance and give scientists a lot of money, along with the freedom to decide what to do with it. Peter Kind (Fig. 3), Director of Directorate B of the EC's Directorate-General for Research, sent out a clear message at the meeting: Do not count on the EU to help you, and if you want to create an ERC, it had better be different to what is already in place, and give 'added value' to European science and research. At the same time, however, the EC seems to have already made up its mind; at least, that would explain why they recently gave $€ 20$ million to the European Science Foundation (ESF) to 'catal$y^{\prime} e^{\prime}$ the Eurohorcs-which represent the
"Nothing is more powerful than an idea whose time has come"

national funding agencies-in what could be seen as a first step towards an ERC. Lost in this entanglement of 'Eurorganizations' and 'E-cronyms', however, would be accountability and independence, as some criticized in private conversations. An ERC run by the Eurohorcs and the ESF, being the platform for the national agencies, would not necessarily be independent of national influences and wishes, which, again, are not necessarily independent of politicians. It would also fail to meet one of the main demands of the scientific community, namely that the ERC should be a new scheme, established and run mostly by scientists.

And industry is not prepared to participate either. "Do not expect any support from the European life science industry, because it is not possible," Horst Domdey from BioM, a service company for biotech start-ups, in Munich, Germany, said. "The pharmaceuti- cal industry is not able to fund science at arm's length," Hans van den Berg, from the Animal Cell Technology Industry Platform, concurred. So, the money needs to come from the governments, who have made their commitment to the $3 \%$ goal. But, as Rolf Tarrach from the Eurohorcs pointed out, they tend not to be accountable, particularly as those politicians who signed the Barcelona statement are unlikely to be in power in 2010. For him, however, this is just one more argument for an ERC: "We still have to do it, precisely because if we do it properly, an ERC will raise some new money." But others felt that politicians also have to be held responsible for their promises. As Connerade pointed out, if the heads of state, "with an arrogant stroke of the pen," sign a commitment, it is their task to fulfil it: "We should turn the question back on them-if they sign the paper, they should tell us where the money comes from."

\section{Holger Breithaupt}

doi:10.1038/sj.embr.embor814

\title{
The ethics of innovation
}

\author{
Should innovative surgery be exempt from clinical trials and regulations?
}

$\mathrm{L}$ ast summer, researchers from the Veterans Affairs Medical Center (Houston, TX, USA) published the startling results of a placebo-controlled study of arthroscopic surgery. At no point, they reported, did the patients in the surgery group report less pain or better functioning of the knee than the patients who received placebo surgery-just cutting the knee without further intervention-according to lead investigator J. Bruce Moseley (Moseley et al., 2002). Scientists have long known about the placebo effects of medical treatments, so the outcome of the study is not necessarily a revelation. What is more surprising is that this type of arthroscopic surgery has never been tested before in a placebo-controlled study to determine its merits, as is the case for many other forms of surgery and surgical techniques. It raises new and serious questions about the ethics and efficiency of surgical practice and other forms of medical intervention, which, unlike new drugs and medical devices, are not subject to rigorous clinical trials.
"Historically, surgical research has not been held to the same scientific, regulatory and ethical standards as other medical research," said Dorothy Vawter, a bioethicist at the University of Minnesota's Center for Bioethics (Minneapolis, MN, USA). There is a growing debate about whether more control is needed over new surgical innovations. At present, only $\sim 7 \%$ of surgical investigators use a randomized-study design of any type, according to a report in The Lancet (1999). Another study found that, during the previous four decades, only $10-20 \%$ of surgical techniques have undergone any clinical trials (Salzman, 1985). "An increasing emphasis on technological innovation and the practice of describing 'new' surgeries to the newspapers before they are formally tested, makes the need for more thoughtful dialogue about what constitutes human research and how to best protect patients' rights even more urgent," commented ophthalmologist and pathologist Curtis Margo in the Journal of Medical Ethics (Margo, 2001). "The distinction between clinical practice and surgical 